\title{
SPECIATION STUDY OF COPPER, LEAD, CHROMIUM, CADMIUM AND NICKEL IN WATERS FROM FISH POND AND STREAM OF OKE-OSUN FARM SETTLEMENT, OSOGBO, SOUTH WESTERN, NIGERIA.
}

\author{
${ }^{*}$ Akinjokun, A.I., ${ }^{\#}$ Oyekunle, J.A.O., ${ }^{\#}$ Egharevba G.O. and ${ }^{\dagger \uparrow}$ Ogunfowokan, A.O. \\ "Department of Industrial Chemistry, Joseph Ayo Babalola University, Ikeji Arakeji, Osun State, Nigeria \\ \#Department of Chemistry, Obafemi Awolowo University, Ile Ife, Nigeria \\ ${ }^{\dagger}$ The Technical University, PMB 5015, GPO Dugbe, Ibadan, Oyo State, Nigeria \\ ${ }^{\ddagger}$ Corresponding Author; E-mail: adebolakinjoks@gmail.com \\ (Received: $13^{\text {th }}$ December, 2017; Accepted: $2^{\text {nd }}$ February, 2018)
}

\section{ABSTRACT}

\begin{abstract}
Speciation of copper, lead, chromium and nickel in waters from a fish pond and stream of a farm settlement in Osogbo, Southwestern Nigeria, was investigated. Wet digestion was used for the extraction of $\mathrm{Pb}, \mathrm{Cr}, \mathrm{Cd}, \mathrm{Cu}$ and $\mathrm{Ni}$ prior to the determination of their concentrations by Atomic Absorption Spectrophotometry (AAS). Packed Amberlite XAD-A16 resin column was used for the pre-concentration and separation of the various species of metals in water samples. The total mean concentration of heavy metals in the pond and stream were: $\mathrm{Cu}, 0.317 \pm 0.005$ and $0.218 \pm 0.031 ; \mathrm{Pb}, 0.026 \pm 0.001$ and $0.032 \pm 0.009 ; \mathrm{Cr}, 0.043 \pm 0.002$ and $0.050 \pm 0.003$; $\mathrm{Cd}, 0.004 \pm 0.001$ and $0.010 \pm 0.005$ and $\mathrm{Ni} 0.233 \pm 0.001$ and $0.233 \pm 0.003 \mathrm{mg} / \mathrm{L}$, respectively. Speciation analysis showed that the concentrations $(\mathrm{mg} / \mathrm{L})$ of all the metal species were in the order: $\mathrm{Cu}>\mathrm{Ni}>\mathrm{Cr}>\mathrm{Pb}>$ $\mathrm{Cd}$ in both the fish pond and stream. There was a significant difference between the mean concentrations of metals in water samples from fish pond and stream $(\mathrm{P} \leq 0.05)$ which strongly suggested that the metals might not have come from the same source. Cluster analysis of metals in the pond and stream samples revealed that the metals could have originated from agricultural runoff, activities on the surrounding farmlands, and vehicular emission, on one hand, and leaching from underlying bedrocks on the other hand.
\end{abstract}

Keyword: Speciation analysis, fish pond, water, metals, farm settlement, Osogbo

${ }^{\S}$ Permanent address: Department of Chemistry, Obafemi Awolowo University, Ile Ife, Nigeria

\section{INTRODUCTION}

The increased use of agrochemicals in agrarian communities has led to concomitant rising levels of heavy metal contaminants in fresh water bodies, especially within the vicinity of the applied agrochemicals. Erosion of soil laden with adsorbed chemicals derived from these agrochemicals such as heavy metals and chlorinated pesticides has rendered water in many rivers and streams unfit for fish farming and human consumption (Shao et al., Ebenstein, 2012). This is a serious problem in agrarian communities in developing nations where people rely on surface water for most of their water needs. These inorganic heavy metals, unlike their organic counterparts, are not biodegradable once released into the environment.

Heavy metals are stable and persistent environmental contaminants and bioaccumulate through the food chain (Gundacker, 2000; Fu and Wang, 2011) inflicting various health effects on humans and animals. Health hazards associated with cadmium, for example, include bone marrow disorder, kidney problem, Itai-Itai disease and testicular atrophy (Salomons and Förstner, 2012). Chromium is involved in the pathogenesis of diseases such as lung and gastrointestinal cancer (Jomova and Valko, 2011).

The common approach for assessing the negative impacts of heavy metals in environmental samples is the measurement of its total concentration (Nemati et al., 2011; Yuan et al., 2011). This approach provides no information about the fate of metals in terms of its bioavailability. Therefore, to fully assess the potential toxicity of metals in the environment, data on the speciation analysis of metals must be considered along with those of the total metal concentration (Sundaray et al., 2011).

\section{MATERIALS AND METHODS}

\section{Sampling site and sample collection}

In this study, three points each across the fish pond and receiving stream on Oke Osun farm settlement were sampled for a period of six months. Sampling points were designated as $\mathrm{P}_{1}, \mathrm{P}_{2}$ 
and $\mathrm{P}_{3}$ and $\mathrm{S}_{1}, \mathrm{~S}_{2}$ and $\mathrm{S}_{3}$ for fish pond and stream respectively. Oke Osun farm settlement lies between latitude $7^{\circ} 44^{\prime} 20^{\prime \prime} \mathrm{N}$ and longitude $4^{\circ} 32^{\prime}$ $20 " \mathrm{E}$ (Figure 1). These samples were collected into pre-treated polyethylene bottles after equilibrating each sampling bottles three times with the water from Fish pond and Stream. Water samples collected from each sampling points were preserved by acidifying with concentrated $\mathrm{HNO}_{3}$ The samples were transported to the Laboratory where it was stored at $4^{\circ} \mathrm{C}$ in the refrigerator prior to analysis.

\section{Apparatus and reagents used}

All glassware, Teflon beakers and polyethylene bottles used were first washed with liquid detergent, rinsed with tap water and distilled water in that order and then soaked in $10 \%(\mathrm{v} / \mathrm{v}) \mathrm{HNO}_{3}$ for 24 hours. They were then re-washed with liquid detergent and thoroughly rinsed with distilled water. Thereafter, the apparatus were thereafter oven-dried for 12 hours at a temperature of $80^{\circ} \mathrm{C}$. All the reagents used viz.: XAD Amberlite Resin A16 (Sigma Aldrich), Acetone, $\mathrm{HNO}_{3}, \mathrm{HClO}_{4}, \mathrm{NaOH}$, and Borax were of analytical grade.

\section{Determination of total heavy metal}

A $50 \mathrm{~mL}$ water sample was digested in Teflon beakers with $5 \mathrm{~mL}$ concentrated $\mathrm{HNO}_{3}$ on a thermostated hot-plate between $150^{\circ} \mathrm{C}$ and $180^{\circ} \mathrm{C}$. The mixture was evaporated to half its volume, and the Teflon beaker with its content was removed from heater and allowed to simmer. Then $5 \mathrm{~mL} \mathrm{HClO}_{4}$ was added and the mixture digested until the emergence of a dense white fume. The Teflon beaker with its content was allowed to cool to room temperature and the content was quantitatively transferred into a 50 $\mathrm{mL}$ volumetric flask and made up to mark with distilled water. A blank determination was carried out using the procedure described above without the sample. The $\mathrm{Cu}, \mathrm{Pb}, \mathrm{Cd}, \mathrm{Cr}$ and $\mathrm{Ni}$ contents were determined using Atomic Absorption Spectrophotometer (AAS) at the International Institute for Tropical Agriculture, Ibadan, Nigeria.

\section{Partitioning of heavy metal species}

The analytical fractionation procedure of Tokalioglu et al. (2000) was used for the partitioning of $\mathrm{Cu}, \mathrm{Pb}, \mathrm{Cd}, \mathrm{Cr}$ and $\mathrm{Ni}$ into bound, particulate and free specie in this study. The procedure involved the fractionation of the water samples into dissolved, particulate and free specie. A $250 \mathrm{~mL}$ volume of water sample was subjected to various treatments on $0.45 \mu \mathrm{m}$ nucleopore membrane filter (47 diameter) and Amberlite XAD A-16 resin to separate the heavy metals into three operationally defined fractions. The resulting fractions were digested and taken for AAS determinations.

\section{Heavy metal attached to particulate matter}

A $50 \mathrm{~mL}$ sample was filtered through an acid washed and oven dried $0.45 \mu \mathrm{m}$ nucleopore membrane filter (47 diameter). Metals attached to suspended particles were retained on the membrane filter. The membrane filter was dissolved in concentrated $\mathrm{HNO}_{3}$ and centrifuged at $150 \mathrm{rpm}$. The acidic fraction was transferred into Teflon beaker and evaporated to near dryness on a hot plate in a fume cupboard. The beaker was removed from the hot plate and allowed to cool to room temperature. Then $2 \mathrm{~mL}$ of $2 \mathrm{molL}^{-1} \mathrm{HNO}_{3}$ was added and the mixture was carefully transferred into a $25 \mathrm{~mL}$ volumetric flask and then made up to the mark with distilled water.

\section{Organically bound heavy metal}

Amberlite resin XAD-A16 resin (particle size 2040 mesh; pore size $10 \mathrm{~nm}$; surface area $825 \mathrm{~m}^{2} \mathrm{~g}^{-1}$ (Sigma-Aldrich) was ground in a mortar (which was pre-treated by washing with dilute acid, large volume of water and later oven dried at $105^{\circ} \mathrm{C}$ for 3 hours) to enlarge the surface area and sieved to 60-80 mesh. The amberlite resin was slurry packed into a $10 \mathrm{~mm} \times 100 \mathrm{~m}$ glass column. The resin was preconditioned by successively washing with methanol, distilled water, 1 molL $^{-1} \mathrm{HNO}_{3}$ in acetone, $1 \mathrm{molL}^{-1} \mathrm{NaOH}$ and distilled water. The column was further preconditioned before the fractionation with about $30 \mathrm{~mL}$ of the sample solution. The filtrate obtained from above was passed through the pre-conditioned column at a flow rate of $2.5 \mathrm{mLmin}^{-1}$. The column effluent was reserved for the free metal specie determinations. The metal adsorbed to the resin was eluted at a flow rate of $1 \mathrm{mLmin}^{-1}$ with $1 \mathrm{molL}$ ${ }^{1} \mathrm{HCl}$ in acetone. The eluate was evaporated to near dryness and the residue obtained was 
dissolved by adding $0.7 \mathrm{~mL} 2 \mathrm{molL}^{-1} \mathrm{HNO}_{3}$. Thereafter, the mixture was transferred to a $25 \mathrm{~mL}$ volumetric flask and made up to the mark with distilled water.

\section{Free metal fraction}

The $\mathrm{pH}$ of the column effluent from the previous step above was adjusted to 7 by adding borax and the solution was then passed through another freshly packed and conditioned column. The trace metal adsorbed on the resin was eluted with 1 molL ${ }^{-1} \mathrm{HCl}$ in acetone. The eluate was evaporated to near dryness and $0.7 \mathrm{~mL}$ of $2 \mathrm{molL}^{-1} \mathrm{HNO}_{3}$ was added to dissolve any particle left undigested. The mixture was transferred into a $25 \mathrm{~mL}$ volumetric flask and made up mark with distilled water.

\section{Quality assurance protocol Blank determination}

A blank was subjected to the same treatment as each sample to nullify the background levels of metals in water and all reagents used.

\section{Recovery analysis}

Accurately measured $25 \mathrm{~mL}$ of sample was transferred into a beaker. This was spiked with 25 $\mathrm{mL}$ of $25 \mu \mathrm{g} / \mathrm{mL}$ of $\mathrm{Pb}, \mathrm{Cu}, \mathrm{Cd}, \mathrm{Cr}$ and $\mathrm{Ni}$ prepared from their nitrate salts and digested using the method already described. The spiked and digested samples were transferred into $25 \mathrm{~mL}$ volumetric flasks and made up to mark with distilled water. $25 \mathrm{~mL}$ each of $25 \mu \mathrm{g} / \mathrm{mL}$ of the $\mathrm{Pb}$, $\mathrm{Cu}, \mathrm{Cr}, \mathrm{Cd}$ and $\mathrm{Ni}$ standards were also taken for AAS analysis. The results obtained were compared with those of spiked water samples to determine the recovery of the analysis. Triplicate analyses were also carried out to further check the reliability and reproducibility of the methods used in this study.

\section{Data analysis}

The mean, standard deviation, Spearman's correlation and cluster analysis of data were determined using the SPSS version 16 software.

\section{RESULTS AND DISCUSSION}

Table 1 contains the results of the recovery study conducted. The results which showed percentage recoveries of $96.23 \pm 3.06 \%$ for $\mathrm{Cu}, 86.38 \pm 3.53$ $\%$ for $\mathrm{Pb}, 89.15 \pm 3.97 \%$ for $\mathrm{Cr}, 93.20 \pm 3.91 \%$ for $\mathrm{Ni}$ and $92.99 \pm 4.55 \%$ for $\mathrm{Cd}$ is an indication that the analytical procedures described were adjudged reliable. The total concentrations of $\mathrm{Cu}$, $\mathrm{Pb}, \mathrm{Cr}, \mathrm{Ni}$ and $\mathrm{Cd}$ in samples from each sampling point show varying degrees of contamination. The monthly mean metal concentrations in water samples from fish pond and stream are presented in Tables 2 to 6 while Table 7 shows the overall mean and range of metals. Figure 2 and 3 shows the sequence of heavy metals distribution in water samples from fish pond and stream.

The monthly mean copper concentration in the pond samples varied from $0.249 \pm 0.002 \mathrm{mg} / \mathrm{L}$ to $0.418 \pm 0.002 \mathrm{mg} / \mathrm{L}$ and from $0.027 \pm 0.001$ $\mathrm{mg} / \mathrm{L}$ to $0.402 \pm 0.001 \mathrm{mg} / \mathrm{L}$ in the stream samples. In the pond, the highest monthly mean $\mathrm{Cu}$ concentration of $0.418 \pm 0.002 \mathrm{mg} / \mathrm{L}$ was recorded at $\mathrm{P}_{1}$ in February and the lowest monthly mean $\mathrm{Cu}$ concentration of $0.249 \pm 0.002 \mathrm{mg} / \mathrm{L}$ was recorded at $\mathrm{P}_{1}$ and $\mathrm{P}_{3}$ in March and February respectively. In the stream samples however, sampling point $S_{1}$ recorded the highest monthly mean concentration of $0.402 \pm 0.001 \mathrm{mg} / \mathrm{L}$ in October while $\mathrm{S}_{3}$ recorded the lowest monthly mean concentration of $0.027 \pm 0.001 \mathrm{mg} / \mathrm{L}$ in November (Table 2). The mean Cu concentrations across sampling points within the pond and stream were not significantly different from each other (at $\mathrm{P}<0.05$ ) (Table 8). Statistically, the mean values of $\mathrm{Cu}$ within the same column followed by the same superscript in the pond and stream samples respectively are not significantly different from each other using the New Duncan multiple range test.

Generally, in the stream samples (S1-S3), mean values of $\mathrm{Cu}$ decreased downstream due to dilution. Similar trend was observed for pond samples except for samples collected in the month of March. These higher levels of $\mathrm{Cu}$ in the pond might be due to the use of $\mathrm{Cu}$ containing fungicides for the treatment of food crops in the vicinity of the pond which is a common practise by farmers in the settlement. Although $\mathrm{Cu}$ is an essential micronutrient because of its involvement in certain human physiological processes (Clemens, 2001; Reichman, 2002) above certain levels it is toxic. The $\mathrm{Cu}$ levels in the pond and stream examined were below the $2.0 \mathrm{mg} / \mathrm{L}$ WHO recommended limit for $\mathrm{Cu}$ in drinking water (WHO, 2006), which gives no cause for concern 
presently.

The monthly lead concentration in the pond ranged between $0.0018 \pm 0.0001 \mathrm{mg} / \mathrm{L}$ and $0.0404 \pm 0.0001 \mathrm{mg} / \mathrm{L}$ while in the stream, it ranged from $0.0228 \pm 0.0001 \mathrm{mg} / \mathrm{L}$ to $0.046 \pm$ $0.001 \mathrm{mg} / \mathrm{L}$. The highest monthly mean concentration of $\mathrm{Pb}(0.0404 \mathrm{mg} / \mathrm{L})$ in pond water was recorded in February at sampling point $\mathrm{P}_{2}$ while the lowest monthly mean concentration $(0.0018 \mathrm{mg} / \mathrm{L})$ was recorded in January at sampling point $\mathrm{P}_{2}$. In the stream samples, the highest monthly mean $\mathrm{Pb}$ concentration $(0.0459$ $\mathrm{mg} / \mathrm{L}$ ) was recorded at sampling points $\mathrm{S}_{2}$ in February while the lowest value $(0.0228 \mathrm{mg} / \mathrm{L})$ was recorded at $\mathrm{S}_{3}$ in November (Table 3). There were significant differences in $\mathrm{Pb}$ concentrations in waters sampled from pond and stream in this study (Table 8). The highest overall mean $\mathrm{Pb}$ concentration was recorded in samples from the stream $(0.032 \mathrm{mg} / \mathrm{L})$ (Figure 2). This may be as a result of influx of $\mathrm{Pb}$ from tyres and parts of vehicles which ply the farm settlement routes into stream water as the stream has no bridge and thus flows across the road. Motor vehicles are known to introduce a number of toxic metals into the atmosphere, which are later deposited on road sides (Ogunfowokan et al., 2004) and subsequently washed into surface water. The overall mean concentrations of lead in this study are higher than the $0.01 \mathrm{mg} / \mathrm{L}$ recommended WHO maximum allowable concentration for drinking water (WHO, 2006). The fact that water from this stream is used for drinking is a cause for concern as it could lead to a wide range of health hazards which includes hearing impairment, interference with red blood formation, renal failure, and increased risks of miscarriages and still births (Edwards, 2013).

The monthly mean chromium concentrations varied between $0.025 \pm 0.001 \mathrm{mg} / \mathrm{L}$ and $0.059 \pm$ $0.002 \mathrm{mg} / \mathrm{L}$ in the pond and between $0.028 \pm$ $0.002 \mathrm{mg} / \mathrm{L}$ and $0.103 \pm 0.002 \mathrm{mg} / \mathrm{L}$ in the receiving stream. The highest monthly mean $(0.059 \mathrm{mg} / \mathrm{L}) \mathrm{Cr}$ in the pond was recorded at $\mathrm{P}_{1}$ in October while the lowest value $(0.025 \pm 0.001$ $\mathrm{mg} / \mathrm{L}$ ) was recorded at $\mathrm{P}_{3}$ in January (Table 4). The highest monthly mean $(0.103 \pm 0.002 \mathrm{mg} / \mathrm{L}) \mathrm{Cr}$ concentration in the stream water samples was obtained $\mathrm{S}_{1}$ in October and the lowest $(0.028 \pm$
$0.002 \mathrm{mg} / \mathrm{L}$ ) was recorded at $\mathrm{S}_{3}$ in January. The $\mathrm{Cr}$ concentrations recorded in this study in the stream are not significantly different from those in the pond (Table 8). The World Health Organisation recommends the maximum limit of $\mathrm{Cr}$ in drinking water as $0.05 \mathrm{mg} / \mathrm{L}$ (WHO, 2006). High toxicity of $\mathrm{Cr}$ in drinking water exceeding $1.0 \mathrm{mg} / \mathrm{L}$ may cause allergic reaction and may eventually lead to carcinogenicity in man (Ogunfowokan et al., 2009).

Cadmium concentration was very low in samples from fish pond and stream, with monthly mean concentration ranging between $0.0018 \pm 0.0001$ $\mathrm{mg} / \mathrm{L}$ and $0.0066 \pm 0.0002 \mathrm{mg} / \mathrm{L}$ in the pond and between $0.0019 \pm 0.0002 \mathrm{mg} / \mathrm{L}$ and $0.0069 \pm$ $0.0001 \mathrm{mg} / \mathrm{L}$ in the stream (Table 6). The highest monthly mean $(0.0066 \pm 0.0002 \mathrm{mg} / \mathrm{L})$ in the pond was recorded at $\mathrm{P}_{1}$ in December and the lowest $(0.0018 \pm 0.0001 \mathrm{mg} / \mathrm{L})$ at $\mathrm{P}_{3}$ in November. The stream recorded the highest monthly mean $(0.0069 \pm 0.0001 \mathrm{mg} / \mathrm{L})$ at $\mathrm{S}_{1}$ in November and the lowest $(0.0019 \pm 0.0002 \mathrm{mg} / \mathrm{L})$ at $\mathrm{S}_{3}$ in February (Table 6). Cd levels recorded in this study in the stream exceed the WHO guideline limit of 0 to $0.003 \mathrm{mg} / \mathrm{L}$ in water for domestic use and drinking (WHO, 2006). In view of the fact that the stream water in this settlement is used for domestic, irrigation and drinking purposes, the high level of $\mathrm{Cd}$ in the stream is of great concern. This limit is also exceeded in the pond, the Target Water Quality Range (TWQR) for Cd in water for aquatic ecosystem is $0.15 \mu \mathrm{g} / \mathrm{L}$ in soft water and $0.25 \mu \mathrm{g} / \mathrm{L}$ in moderately soft water (Nevondo, 1999) and these values were exceeded in the pond. Therefore the water in the pond will not be suitable for aquatic ecosystem sustenance. Cadmium in the stream and pond is likely to be from underlying bedrocks and runoffs from farmlands on which fertilisers which contain $\mathrm{Cd}$, a common impurity, is used (Järup, 2003; Alloway, 2013). Cadmium has been found to be toxic to fish and other aquatic organisms and can cause adverse health effects to consumers such as renal disease and cancer (Ogunfowokan et al., 2009).

The monthly mean levels of $\mathrm{Ni}$ varied between $0.143 \pm 0.002 \mathrm{mg} / \mathrm{L}$ and $0.3139 \pm 0.0002 \mathrm{mg} / \mathrm{L}$ in the pond and between $0.023 \pm 0.002 \mathrm{mg} / \mathrm{L}$ and $0.389 \pm 0.002 \mathrm{mg} / \mathrm{L}$ in the receiving stream. The highest monthly mean $(0.3139 \pm 0.0002 \mathrm{mg} / \mathrm{L})$ in 
the pond was obtained at $\mathrm{P}_{1}$ in January and the lowest $(0.143 \pm 0.002 \mathrm{mg} / \mathrm{L})$ at $\mathrm{P}_{2}$ in December. In the receiving stream; the highest mean $(0.389 \pm$ $0.002 \mathrm{mg} / \mathrm{L}$ ) was recorded at $\mathrm{S}_{1}$ in January and the lowest $(0.023 \pm 0.0002 \mathrm{mg} / \mathrm{L})$ at $\mathrm{S}_{3}$ in November (Table 5). The overall mean concentration of Ni in the pond and stream $(0.231 \pm 0.001 \mathrm{mg} / \mathrm{L}$ and $0.236 \pm 0.001 \mathrm{mg} / \mathrm{L}$ respectively) (Table) were below the WHO maximum allowable concentration of $20 \mu \mathrm{g} / \mathrm{L}$ in drinking water. Hence, water in the pond and stream in OkeOsun farm settlement do not pose any threat to aquatic organisms in the pond and humans using the water as far as Ni levels were concerned.

The cluster analysis of sample data from pond and stream revealed two different clusters. Figures 3 and 4 are dendrograms showing clusters of the analysed elements. In the fish pond data set, cluster 1 showed $\mathrm{Pb}, \mathrm{Cd}$ and $\mathrm{Ni}$ while the elements $\mathrm{Cu}$ and $\mathrm{Cr}$ are grouped in cluster 2. The clustering of the stream data shows that the elements $\mathrm{Cu}, \mathrm{Ni}$, and $\mathrm{Cr}$ are contained in cluster 1 whereas $\mathrm{Cd}$ and $\mathrm{Pb}$ are contained in cluster 2. The groupings suggest that elements in a particular group/cluster are strongly correlated and may probably have originated from a common source.

The result of the speciation analysis of $\mathrm{Pb}, \mathrm{Cu}, \mathrm{Cr}$, $\mathrm{Cd}$ and $\mathrm{Ni}$ are as presented in Table 9 which shows the mean levels of metals in the various fractions. The sequence of the overall mean $\mathrm{Cu}$ concentrations in decreasing order is: organic bound $>$ free $>$ suspended in pond and suspended $>$ Free $>$ bound in stream (Tables 8 and Figure 4 ).

Copper in the organic bound fraction / specie recorded the highest $(0.120 \mathrm{mg} / \mathrm{L})$ overall mean concentration in the pond (Table 8 ). This could be due to a high level of dissolved organic carbon (DOC) and/or suspended solids in pond. DOC binds strongly with copper thereby reducing its availability to aquatic organisms and (Stumm and Morgan, 1996). This indicates that majority of copper species are organically bound and hence not available for uptake. Based on this, the water in fish pond is therefore safe for sustainable aquaculture as far as copper speciation is concerned. The $\mathrm{pH}$ of the water should be monitored closely as its reduction could cause $\mathrm{Cu}$ to dissociate from $\mathrm{Cu}$-organic complexes and change the speciation of copper to one dominated by the free copper specie. This would be dangerous as the free $\mathrm{Cu}$ specie $\left(\mathrm{Cu}^{2+}\right)$ is the most toxic and could cause deleterious side effects in man and aquatic organisms. The overall mean copper level of the bound fraction is proportionate to the concentration of other fractions in stream water.

In this study, results of speciation analysis of $\mathrm{Pb}$ in the pond water samples gave the overall mean concentration of $\mathrm{Pb}$ in the following decreasing order: organic bound $>$ suspended $>$ free. The reason why most of the $\mathrm{Pb}$ is in the organic form/specie is probably due to the high humic acids and fluvic acid in the pond. In the stream, the sequence was reversed and the overall mean $\mathrm{Pb}$ concentrations in decreasing order followed the sequence: bound $>$ free $>$ suspended (Figure 4 and Table 8). The ratio of bound to free $\mathrm{Pb}$ species recorded in this study was approximately 2.0 for pond and 1.0 for stream (Table9). This shows that the organic bound $\mathrm{Pb}$ dominates the speciation in the pond according to Tokalioglu et al. (2000). Speciation measurements therefore suggests that $\mathrm{Pb}$ was strongly complexed by organic acids in pond and that a steady state conditions existed between free and organic bound metal species in stream water. This is consistent with the findings that the bound $\mathrm{Pb}$ species controls $\mathrm{Pb}$ speciation in water and that elevated water velocity coupled with other factors such as biological activities, temperature and change in water chemistry in a river could cause re-suspension of previously complexed or dissolved particles and lead to higher concentrations of suspended particles as seen in stream in this study (Gobeil et al., 1987).

The ratios of organic bound to free forms of $\mathrm{Cr}$ are similar in pond and stream, i.e. approximately $=1$ (Table8). This shows that the free and the organic bound forms are in the same proportion. These call for urgent and immediate actions to reduce the free species which are known to be highly soluble in water and could permeate biological membrane owing to its oxidising potential. Free $\mathrm{Cr}$ species have been implicated in the pathogenesis of many diseases such as gastrointestinal cancer (Comber and Gardner, 2003). The three fractions are in the same proportion in this study; this is in agreement with 
the result reported by Tokalioglu et al. (2000).

The distribution of $\mathrm{Cd}$ species followed the sequence: free $>$ suspended $>$ organic bound in stream water. In pond however, the order of the sequence was organic bound $>$ suspended $>$ free (Figure 4 and Table 8 ). The ratio of organic bound to free cadmium species $(0.88)$ in stream and pond (1.2) shows that the organically bound and free forms are in the same proportion.

\section{CONCLUSION}

The speciation study of heavy metals revealed that most of the metals were bound to suspended matters and the degree of partitioning of metal species in pond and stream is very low. The sequence of metal species distribution reported in this study could shift at any slight change in the water chemistry. The organic bound metal species could become bioavailable when subjected to varying physico-chemical variables like $\mathrm{pH}$, temperature and redox potential change. Thus, considering the organic bound specie in addition to the suspended species, the percentage bioavailable $\mathrm{Pb}, \mathrm{Cu}, \mathrm{Cr}, \mathrm{Ni}$ and $\mathrm{Cd}$ might be up to $65 \%, 68 \%, 56 \%, 66 \%$ and $78 \%$ respectively in the pond and $59 \%, 67 \%, 58 \%, 63 \%$ and $66 \%$ respectively in the stream. . The results of speciation study showed that most of the metals were bound to suspended matters.

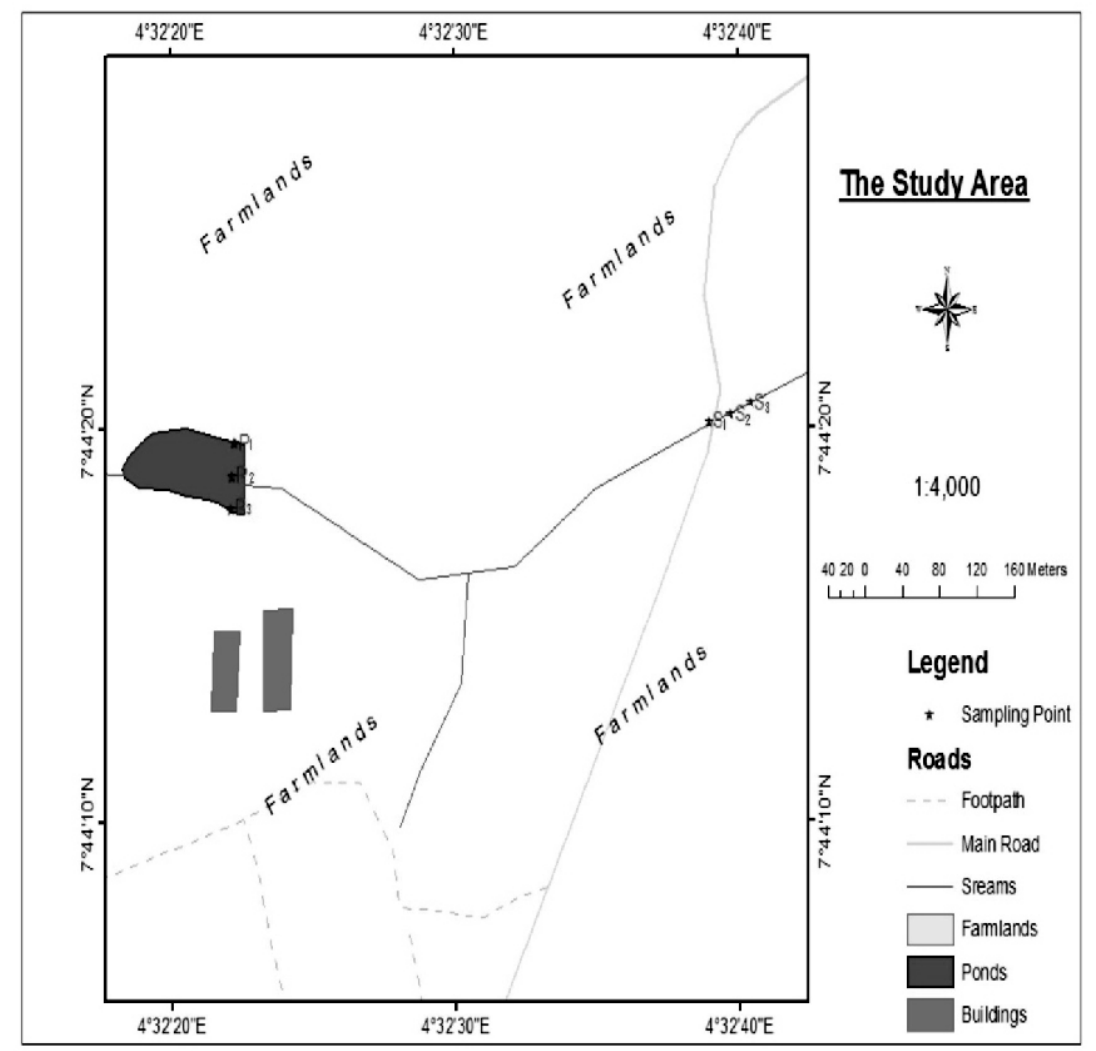

Figure 1: Map of the study area showing location of sampling points at Oke-Osun Farm Settlement, Osogbo

Table 1: Calibration Curve and \% Recovery for Metals

\begin{tabular}{lll}
\hline Element & $\begin{array}{l}\text { Calibration Curve, } \\
\mathrm{r}^{2}\end{array}$ & $\begin{array}{l}\text { \% Recovery of } \\
\text { elements* }\end{array}$ \\
\hline $\mathrm{Pb}$ & 0.959 & $86.38 \pm 3.53$ \\
$\mathrm{Cu}$ & 0.979 & $96.23 \pm 3.06$ \\
$\mathrm{Cr}$ & 0.989 & $89.15 \pm 3.97$ \\
$\mathrm{Ni}$ & 0.997 & $93.20 \pm 3.91$ \\
$\mathrm{Cd}$ & 0.998 & $92.99 \pm 4.55$ \\
\hline
\end{tabular}

$*$ Values are mean of triplicate analysis \pm RSD 
Table 2: Monthly mean concentration of total $\mathrm{Cu}(\mathrm{mg} / \mathrm{L})$ in water samples from fish pond and receiving stream

\begin{tabular}{lllllll}
\hline Site/Month & October & November & December & January & February & March \\
\hline $\mathrm{P}_{1}$ & $0.353 \pm 0.001^{\mathrm{c}}$ & $0.275 \pm 0.005^{\mathrm{c}}$ & $0.407 \pm 0.001^{\mathrm{c}}$ & $0.298 \pm 0.001^{\mathrm{c}}$ & $0.418 \pm 0.002^{\mathrm{c}}$ & $0.249 \pm 0.001^{\mathrm{a}}$ \\
$\mathrm{P}_{2}$ & $0.323 \pm 0.004^{\mathrm{b}}$ & $0.263 \pm 0.001^{\mathrm{b}}$ & $0.393 \pm 0.001^{\mathrm{b}}$ & $0.292 \pm 0.001^{\mathrm{b}}$ & $0.282 \pm 0.001^{\mathrm{b}}$ & $0.365 \pm 0.001^{\mathrm{c}}$ \\
$\mathrm{P}_{3}$ & $0.308 \pm 0.005^{\mathrm{a}}$ & $0.256 \pm 0.002^{\mathrm{a}}$ & $0.376 \pm 0.001^{\mathrm{a}}$ & $0.289 \pm 0.002^{\mathrm{a}}$ & $0.249 \pm 0.002^{\mathrm{a}}$ & $0.313 \pm 0.002^{\mathrm{b}}$ \\
$\mathrm{S}_{1}$ & $0.402 \pm 0.001^{\mathrm{c}}$ & $0.304 \pm 0.001^{\mathrm{c}}$ & $0.236 \pm 0.001^{\mathrm{c}}$ & $0.332 \pm 0.001^{\mathrm{c}}$ & $0.243 \pm 0.002^{\mathrm{a}}$ & $0.302 \pm 0.001^{\mathrm{c}}$ \\
$\mathrm{S}_{2}$ & $0.381 \pm 0.001^{\mathrm{b}}$ & $0.278 \pm 0.001^{\mathrm{b}}$ & $0.226 \pm 0.001^{\mathrm{b}}$ & $0.306 \pm 0.001^{\mathrm{b}}$ & $0.288 \pm 0.001^{\mathrm{c}}$ & $0.293 \pm 0.001^{\mathrm{b}}$ \\
$\mathrm{S}_{3}$ & $0.364 \pm 0.001^{\mathrm{a}}$ & $0.027 \pm 0.001^{\mathrm{a}}$ & $0.223 \pm 0.001^{\mathrm{a}}$ & $0.299 \pm 0.002^{\mathrm{a}}$ & $0.260 \pm 0.010^{\mathrm{b}}$ & $0.289 \pm 0.002^{\mathrm{a}}$ \\
\hline
\end{tabular}

Values are mean \pm Standard Deviation; Values are mean \pm Standard Deviation; Values with the same superscript within the same row are not significantly different from each other using new Duncan multiple range test.

Table 3: Monthly mean concentration $(\mathrm{mg} / \mathrm{L})$ of total $\mathrm{Pb}$ in pond and stream water samples

\begin{tabular}{lllllll}
\hline Site/Month & October & November & December & January & February & March \\
\hline $\mathrm{P}_{1}$ & $0.0273 \pm 0.0001^{\mathrm{c}}$ & $0.0179 \pm 0.0002^{\mathrm{b}}$ & $0.0333 \pm 0.0001^{\mathrm{c}}$ & $0.0218 \pm 0.0002^{\mathrm{c}}$ & $0.0384 \pm 0.0001^{\mathrm{a}}$ & $0.0393 \pm 0.000^{\mathrm{c}}$ \\
$\mathrm{P}_{2}$ & $0.0243 \pm 0.0001^{\mathrm{b}}$ & $0.0177 \pm 0.0001^{\mathrm{b}}$ & $0.0293 \pm 0.0001^{\mathrm{b}}$ & $0.0018 \pm 0.0000^{\mathrm{b}}$ & $0.0404 \pm 0.0001^{\mathrm{b}}$ & $0.0278 \pm 0.0002^{\mathrm{b}}$ \\
$\mathrm{P}_{3}$ & $0.0233 \pm 0.0001^{\mathrm{a}}$ & $0.0153 \pm 0.0001^{\mathrm{a}}$ & $0.0278 \pm 0.0001^{\mathrm{a}}$ & $0.0173 \pm 0.0001^{\mathrm{a}}$ & $0.0384 \pm 0.0002^{\mathrm{a}}$ & $0.0242 \pm 0.0002^{\mathrm{a}}$ \\
$\mathrm{S}_{1}$ & $0.0308 \pm 0.0001^{\mathrm{c}}$ & $0.0258 \pm 0.0001^{\mathrm{c}}$ & $0.0358 \pm 0.0001^{\mathrm{c}}$ & $0.0288 \pm 0.0002^{\mathrm{c}}$ & $0.0374 \pm 0.0001^{\mathrm{a}}$ & $0.0364 \pm 0.0001^{\mathrm{c}}$ \\
$\mathrm{S}_{2}$ & $0.0283 \pm 0.0002^{\mathrm{b}}$ & $0.0238 \pm 0.0001^{\mathrm{b}}$ & $0.0338 \pm 0.0001^{\mathrm{b}}$ & $0.0273 \pm 0.0001^{\mathrm{b}}$ & $0.0459 \pm 0.0001^{\mathrm{c}}$ & $0.0344 \pm 0.0002^{\mathrm{b}}$ \\
$\mathrm{S}_{3}$ & $0.0273 \pm 0.0001^{\mathrm{a}}$ & $0.0228 \pm 0.0001^{\mathrm{a}}$ & $0.0323 \pm 0.0001^{\mathrm{a}}$ & $0.0263 \pm 0.0001^{\mathrm{a}}$ & $0.0429 \pm 0.0001^{\mathrm{b}}$ & $0.0329 \pm 0.0002^{\mathrm{a}}$ \\
\hline
\end{tabular}

Values are mean \pm Standard Deviation; Values are mean \pm Standard Deviation; Values with the same superscript within the same row are not significantly different from each other using new Duncan multiple range test.

Table 4: Monthly mean concentration $(\mathrm{mg} / \mathrm{L})$ of total $\mathrm{Cr}$ in pond and stream water samples

\begin{tabular}{lllllll}
\hline Site/Month & October & November & December & January & February & March \\
\hline $\mathrm{P}_{1}$ & $0.0585 \pm 0.0021^{\mathrm{b}}$ & $0.0393 \pm 0.0001^{\mathrm{c}}$ & $0.0563 \pm 0.0002^{\mathrm{c}}$ & $0.0269 \pm 0.0001^{\mathrm{c}}$ & $0.0384 \pm 0.0002^{\mathrm{a}}$ & $0.0424 \pm 0.0001^{\mathrm{a}}$ \\
$\mathrm{P}_{2}$ & $0.0563 \pm 0.0002^{\mathrm{b}}$ & $0.0338 \pm 0.0002^{\mathrm{b}}$ & $0.0508 \pm 0.0004^{\mathrm{b}}$ & $0.0254 \pm 0.0001^{\mathrm{b}}$ & $0.0439 \pm 0.0002^{\mathrm{c}}$ & $0.0564 \pm 0.0001^{\mathrm{c}}$ \\
$\mathrm{P}_{3}$ & $0.0531 \pm 0.0010^{\mathrm{a}}$ & $0.0303 \pm 0.0001^{\mathrm{a}}$ & $0.0471 \pm 0.0001^{\mathrm{a}}$ & $0.0249 \pm 0.0001^{\mathrm{a}}$ & $0.0394 \pm 0.0001^{\mathrm{b}}$ & $0.0534 \pm 0.0001^{\mathrm{b}}$ \\
$\mathrm{S}_{1}$ & $0.103 \pm 0.00020^{\mathrm{c}}$ & $0.0523 \pm 0.0001^{\mathrm{c}}$ & $0.0378 \pm 0.0001^{\mathrm{c}}$ & $0.0314 \pm 0.0001^{\mathrm{c}}$ & $0.0384 \pm 0.0002^{\mathrm{a}}$ & $0.0534 \pm 0.0001^{\mathrm{c}}$ \\
$\mathrm{S}_{2}$ & $0.096 \pm 0.00020^{\mathrm{b}}$ & $0.0453 \pm 0.0002^{\mathrm{b}}$ & $0.0343 \pm 0.0001^{\mathrm{a}}$ & $0.0294 \pm 0.0002^{\mathrm{b}}$ & $0.0474 \pm 0.0001^{\mathrm{c}}$ & $0.0464 \pm 0.0001^{\mathrm{b}}$ \\
$\mathrm{S}_{3}$ & $0.093 \pm 0.00010^{\mathrm{a}}$ & $0.0428 \pm 0.0002^{\mathrm{a}}$ & $0.0348 \pm 0.0001^{\mathrm{b}}$ & $0.0284 \pm 0.0002^{\mathrm{a}}$ & $0.0444 \pm 0.0001^{\mathrm{b}}$ & $0.0434 \pm 0.0001^{\mathrm{a}}$ \\
\hline
\end{tabular}

Values are mean \pm Standard Deviation; Values are mean \pm Standard Deviation; Values with the same superscript within the same row are not significantly different from each other using new Duncan multiple range test.

Table 5: Monthly mean concentration $(\mathrm{mg} / \mathrm{L})$ of total Ni in pond and stream water samples

\begin{tabular}{lllllll}
\hline Site/Month & October & November & December & January & February & March \\
\hline $\mathrm{P}_{1}$ & $0.215 \pm 0.001^{\mathrm{c}}$ & $0.263 \pm 0.002^{\mathrm{c}}$ & $0.157 \pm 0.020^{\mathrm{c}}$ & $0.314 \pm 0.002^{\mathrm{c}}$ & $0.290 \pm 0.002^{\mathrm{c}}$ & $0.238 \pm 0.002^{\mathrm{b}}$ \\
$\mathrm{P}_{2}$ & $0.205 \pm 0.001^{\mathrm{b}}$ & $0.239 \pm 0.002^{\mathrm{b}}$ & $0.143 \pm 0.002^{\mathrm{a}}$ & $0.273 \pm 0.001^{\mathrm{b}}$ & $0.264 \pm 0.002^{\mathrm{b}}$ & $0.198 \pm 0.002^{\mathrm{a}}$ \\
$\mathrm{P}_{3}$ & $0.201 \pm 0.001^{\mathrm{a}}$ & $0.232 \pm 0.002^{\mathrm{a}}$ & $0.150 \pm 0.002^{\mathrm{b}}$ & $0.258 \pm 0.002^{\mathrm{a}}$ & $0.247 \pm 0.001^{\mathrm{a}}$ & $0.263 \pm 0.010^{\mathrm{c}}$ \\
$\mathrm{S}_{1}$ & $0.143 \pm 0.002^{\mathrm{c}}$ & $0.264 \pm 0.002^{\mathrm{b}}$ & $0.238 \pm 0.001^{\mathrm{c}}$ & $0.389 \pm 0.002^{\mathrm{c}}$ & $0.245 \pm 0.001^{\mathrm{a}}$ & $0.257 \pm 0.002^{\mathrm{c}}$ \\
$\mathrm{S}_{2}$ & $0.142 \pm 0.001^{\mathrm{b}}$ & $0.264 \pm 0.020^{\mathrm{b}}$ & $0.214 \pm 0.001^{\mathrm{b}}$ & $0.366 \pm 0.002^{\mathrm{b}}$ & $0.278 \pm 0.002^{\mathrm{c}}$ & $0.249 \pm 0.002^{\mathrm{b}}$ \\
$\mathrm{S}_{3}$ & $0.129 \pm 0.001^{\mathrm{a}}$ & $0.023 \pm 0.002^{\mathrm{a}}$ & $0.197 \pm 0.002^{\mathrm{a}}$ & $0.357 \pm 0.010^{\mathrm{a}}$ & $0.254 \pm 0.003^{\mathrm{b}}$ & $0.245 \pm 0.002^{\mathrm{a}}$ \\
\hline
\end{tabular}

Values are mean \pm Standard Deviation; Values are mean \pm Standard Deviation; Values with the same superscript within the same row are not significantly different from each other using new Duncan multiple range test. 
Table 6: Monthly mean concentration (mg/L) of total Cadmium in Pond and stream

\begin{tabular}{lllllll}
\hline Site/Month & October & November & December & January & February & March \\
\hline $\mathrm{P}_{1}$ & $0.0026 \pm 0.0002^{\mathrm{b}}$ & $0.0037 \pm 0.0003^{\mathrm{c}}$ & $0.0066 \pm 0.0002^{\mathrm{b}}$ & $0.0043 \pm 0.0003^{\mathrm{c}}$ & $0.0029 \pm 0.0002^{\mathrm{b}}$ & $0.0059 \pm 0.0001^{\mathrm{b}}$ \\
$\mathrm{P}_{2}$ & $0.0023 \pm 0.0001^{\mathrm{a}}$ & $0.0025 \pm 0.0004^{\mathrm{b}}$ & $0.0054 \pm 0.0001^{\mathrm{a}}$ & $0.0038 \pm 0.0001^{\mathrm{b}}$ & $0.0024 \pm 0.0002^{\mathrm{a}}$ & $0.0044 \pm 0.0004^{\mathrm{a}}$ \\
$\mathrm{P}_{3}$ & $0.0023 \pm 0.0002^{\mathrm{a}}$ & $0.0018 \pm 0.0001^{\mathrm{a}}$ & $0.0055 \pm 0.00001^{\mathrm{a}}$ & $0.0028 \pm 0.0001^{\mathrm{a}}$ & $0.0024 \pm 0.0001^{\mathrm{a}}$ & $0.0025 \pm 0.0009^{\mathrm{c}}$ \\
$\mathrm{S}_{1}$ & $0.0063 \pm 0.00003^{\mathrm{c}}$ & $0.0069 \pm 0.0001^{\mathrm{b}}$ & $0.0044 \pm 0.0004^{\mathrm{b}}$ & $0.00068 \pm 0.0001^{\mathrm{b}}$ & $0.0034 \pm 0.00025^{\mathrm{c}}$ & $0.0549 \pm 0.0003^{\mathrm{b}}$ \\
$\mathrm{S}_{2}$ & $0.0053 \pm 0.0002^{\mathrm{b}}$ & $0.0053 \pm 0.0001^{\mathrm{b}}$ & $0.0034 \pm 0.0001^{\mathrm{a}}$ & $0.0063 \pm 0.0002^{\mathrm{b}}$ & $0.0023 \pm 0.0002^{\mathrm{b}}$ & $0.0049 \pm 0.0002^{\mathrm{a}}$ \\
$\mathrm{S}_{3}$ & $0.0046 \pm 0.0002^{\mathrm{a}}$ & $0.0044 \pm 0.0002^{\mathrm{a}}$ & $0.0034 \pm 0.0002^{\mathrm{a}}$ & $0.0048 \pm 0.0004^{\mathrm{a}}$ & $0.0019 \pm 0.0002^{\mathrm{a}}$ & $0.0544 \pm 0.0002^{\mathrm{b}}$ \\
\hline
\end{tabular}

Values are mean \pm Standard Deviation; Values are mean \pm Standard Deviation; Values with the same superscript within the same row are not significantly different from each other using new Duncan multiple range test.

Table 7: Overall Mean and Range of Heavy Metals Concentration $(\mathrm{mg} / \mathrm{L})$ in water samples from Fish Pond and Stream

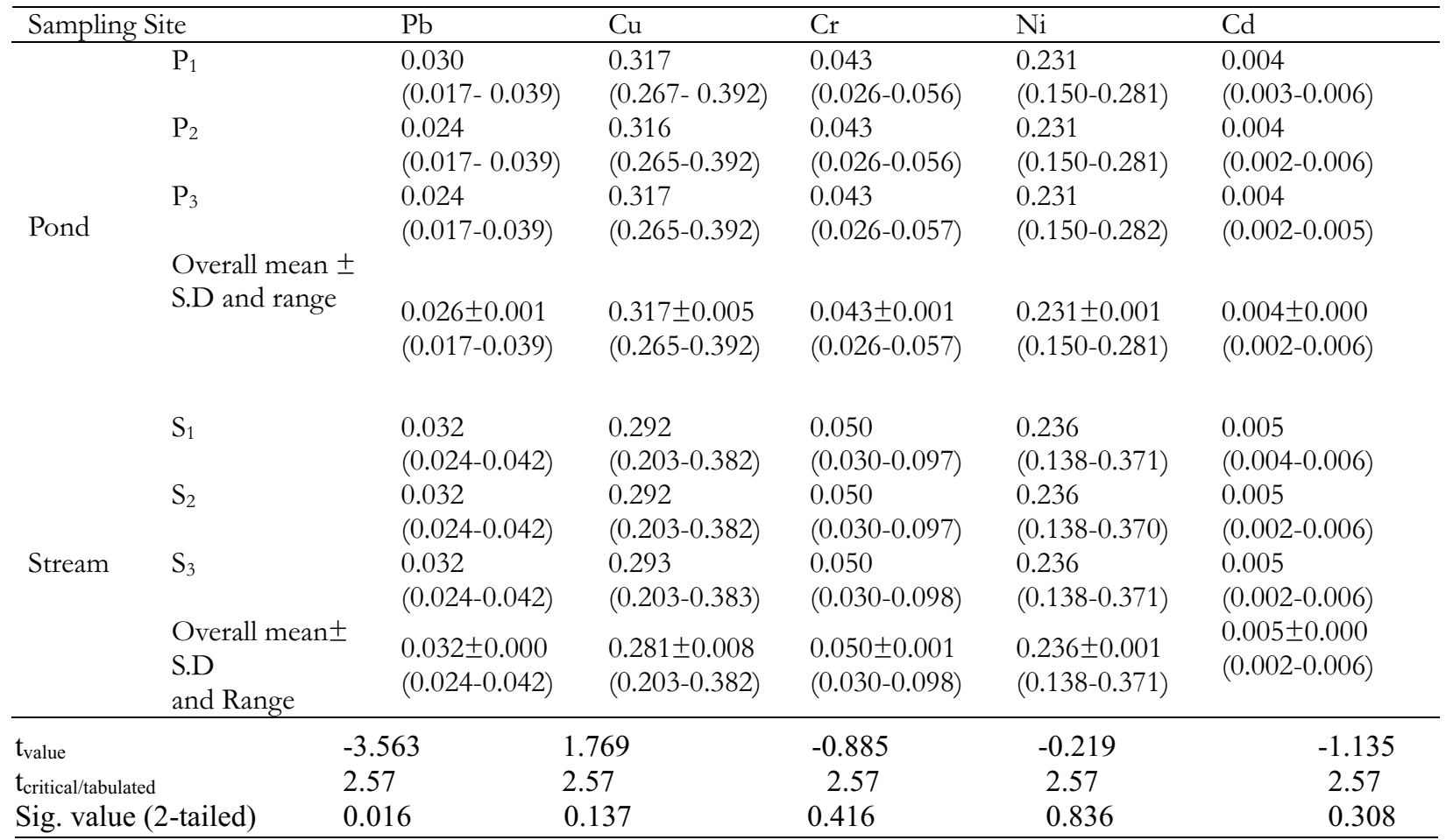

\section{Rescaled Distance Cluster Combine}

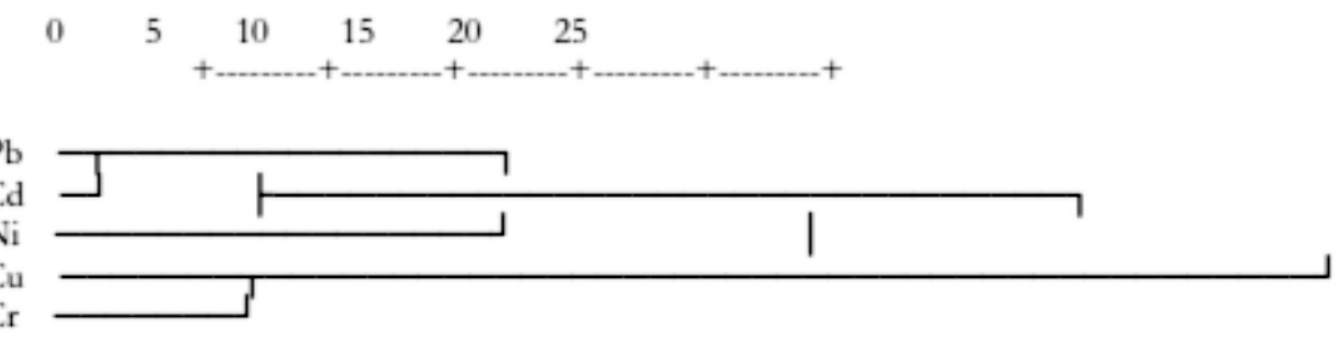

Figure 2: Dendrogram of the measured elements in fish pond water 
Rescaled Distance Cluster Combine
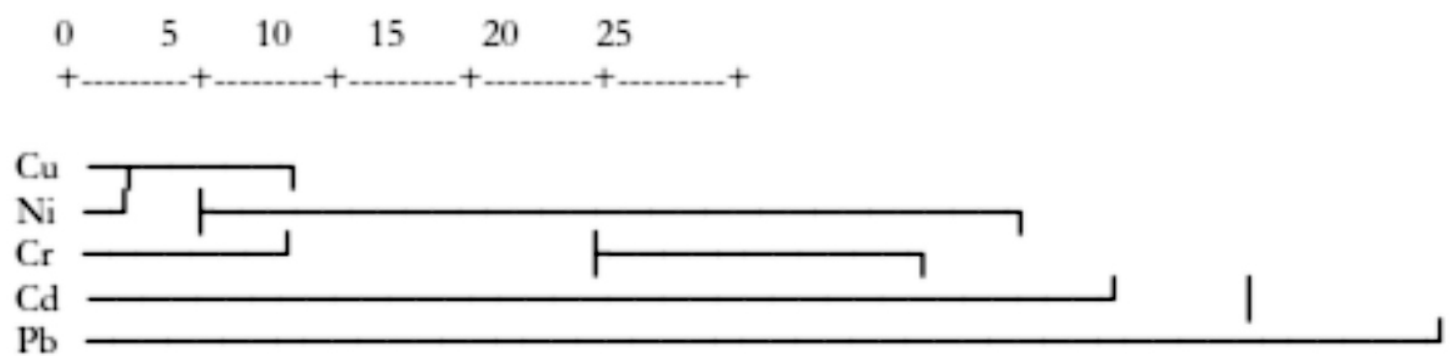

Figure 3: Dendrogram of the measured elements in stream water

Table 8: Metal levels $(\mathrm{mg} / \mathrm{L})$ in different fractions in pond and stream

\begin{tabular}{lllllll}
\hline Sample & & $\mathrm{A}(\mathrm{mg} / \mathrm{L})$ & $\mathrm{B}(\mathrm{mg} / \mathrm{L})$ & $\mathrm{C}(\mathrm{mg} / \mathrm{L})$ & Total & $\mathrm{B} / \mathrm{C}$ \\
\hline Pond & $\mathrm{Pb}$ & $0.007 \pm 0.005$ & $0.010 \pm 0.001$ & $0.006 \pm 0.001$ & 0.023 & 1.64 \\
Stream & & $0.005 \pm 0.001$ & $0.006 \pm 0.003$ & $0.057 \pm 0.002$ & 0.018 & 1.02 \\
Pond & $\mathrm{Cu}$ & $0.107 \pm 0.004$ & $0.120 \pm 0.006$ & $0.114 \pm 0.006$ & 0.341 & 1.05 \\
Stream & & $0.091 \pm 0.003$ & $0.087 \pm 0.003$ & $0.088 \pm 0.003$ & 0.266 & 0.98 \\
Pond & $\mathrm{Cr}$ & $0.015 \pm 0.001$ & $0.010 \pm 0.000$ & $0.010 \pm 0.001$ & 0.035 & 1.00 \\
Stream & & $0.015 \pm 0.001$ & $0.014 \pm 0.001$ & $0.013 \pm 0.001$ & 0.042 & 1.03 \\
Pond & $\mathrm{Ni}$ & $0.045 \pm 0.001$ & $0.040 \pm 0.004$ & $0.039 \pm 0.001$ & 0.124 & 1.00 \\
Stream & & $0.040 \pm 0.001$ & $0.039 \pm 0.001$ & $0.040 \pm 0.001$ & 0.119 & 0.98 \\
Pond & $\mathrm{Cd}$ & $0.001 \pm 0.004$ & $0.001 \pm 0.001$ & $0.001 \pm 0.001$ & 0.003 & 1.10 \\
Stream & & $0.001 \pm 0.001$ & $0.002 \pm 0.001$ & $0.001 \pm 0.001$ & 0.003 & 2.44 \\
\hline
\end{tabular}

$A=$ Suspended metal Specie $\mathrm{B}=$ Organic bound metal specie $\mathrm{C}=$ Free metal specie

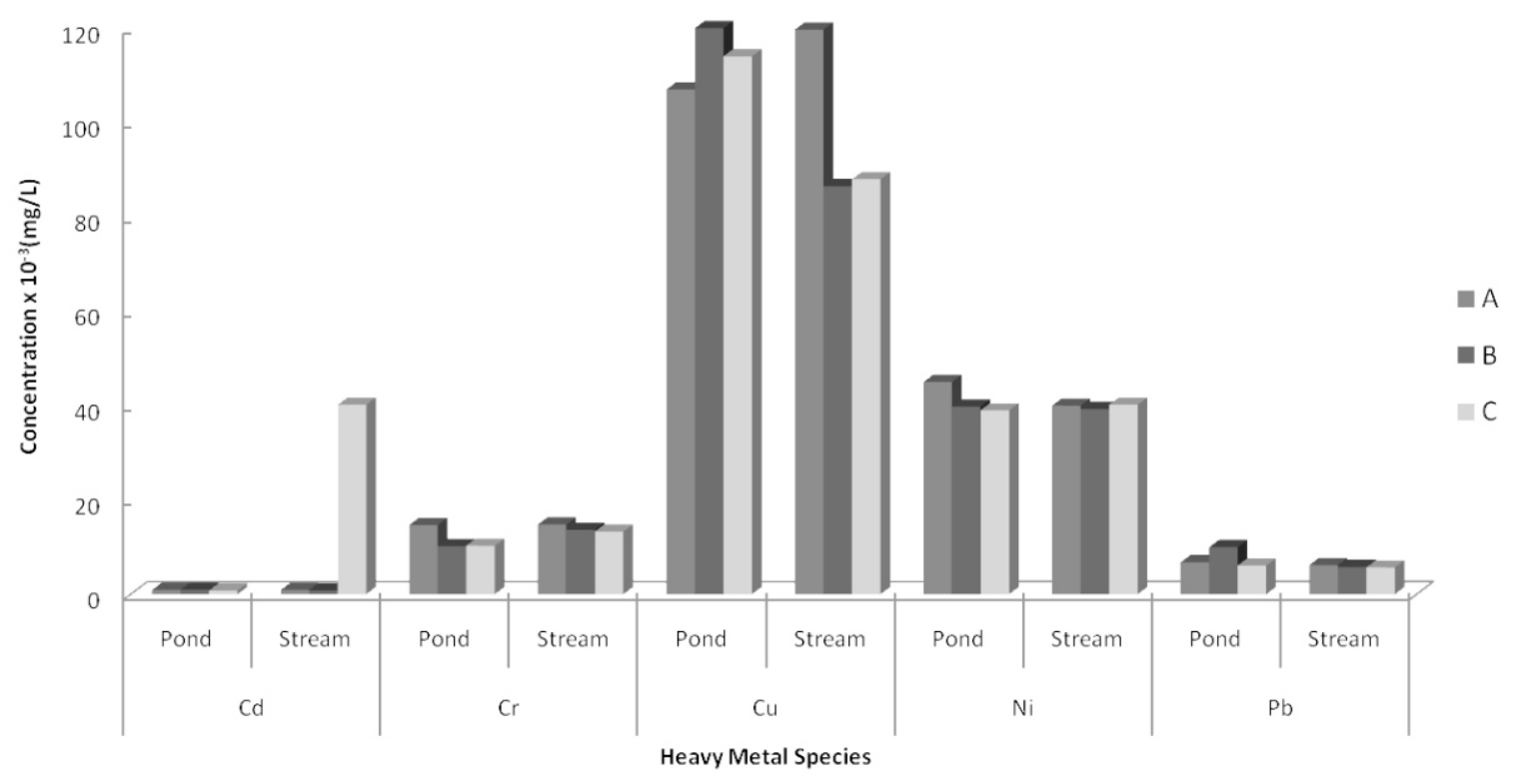
A: Suspended Metal Species,
B: Organic bound metal species,
C: Free (Hydrated) metal species.

Figure 4: Variation in mean concentrations of heavy metal species 


\section{REFERENCES}

Alloway, B. J. 2013. Sources of heavy metals and metalloids in soils Heavy metals in soils, pp. 11-50, Springer.

Clemens, S. 2001. Molecular mechanisms of plant metal tolerance and homeostasis. Planta, 212(4), 475-486.

Comber, S. and Gardner, M. 2003. Chromium redox speciation in natural waters. Journal of EnvironmentalMonitoring, 5(3), 410-413.

Ebenstein, A. 2012. The consequences of industrialization: evidence from water pollution and digestive cancers in China. Review of Economics and Statistics, 94(1), 186201.

Edwards, M. 2013. Fetal death and reduced birth rates associated with exposure to leadcontaminated drinking water. Environmental Science and Technology, 48(1), 739-746.

Fu, F. and Wang, Q. 2011. Removal of heavy metal ions from wastewaters: a review. Journal of EnvironmentalManagement, 92(3), 407-418.

Gobeil, C., Silverberg, N., Sundby, B. and Cossa, D. 1987. Cadmium diagenesis in Laurentian Trough sediments. Geochimica et Cosmochimica Acta, 51(3), 589-596.

Gundacker, C. 2000. Comparison of heavy metal bioaccumulation in freshwater molluscs of urban river habitats in Vienna. EnvironmentalPollution, 110(1), 61-71.

Järup, L. 2003. Hazards of heavy metal contamination. British Medical Bulletin, 68(1), 167-182.

Jomova, K. and Valko, M. 2011. Advances in metal-induced oxidative stress and human disease. Toxicology, 283(2), 65-87.

Nemati, K., Bakar, N. K. A., Abas, M. R. and Sobhanzadeh, E. 2011. Speciation of heavy metals by modified BCR sequential extraction procedure in different depths of sediments from Sungai Buloh, Selangor, Malaysia. Journal of Hazardous Materials, 192(1), 402-410.
Nevondo, T. and Cloete, T.E. 1999. Bacterial and chemical quality of water supply in the Dertig village settlement. Water $S A, 25(2)$, $215-220$.

Ogunfowokan, A., Asubiojo, O., Adeniyi, A. and Oluyemi, E. (2004). Trace lead, zinc, and copper levels in Barbula lambarenensis as a monitor of local atmospheric pollution in Ile-Ife, Nigeria. Journal of Applied Sciences, 4(3), 380-383.

Ogunfowokan, A.O., Oyekunle, J.A.O., Durosinmi, L.M., Akinjokun, A. and Gabriel, O.D. 2009. Speciation study of lead and manganese in roadside dusts from major roads in Ile-Ife, South Western Nigeria. Chemistry and Ecology, 25(6), 405-415.

Reichman, S. 2002. The Responses of Plants to Metal Toxicity: A Review Focusing on Copper, Manganese and Zinc. Australian Minerals and Energy Environment Foundation Melbourne.

Salomons, W. and Förstner, U. 2012. Metals in the Hydrocycle: Springer Science and Business Media.

Shao, M., Tang, X., Zhang, Y. and Li, W. 2006. City clusters in China: air and surface water pollution. Frontiers in Ecology and the Environment, 4(7), 353-361.

Stumm, W. and Morgan, J. 1996. Aquatic Chemistry New York. NY, John Wiley and Sons.

Sundaray, S. K., Nayak, B. B., Lin, S. and Bhatta, D. 2011. Geochemical speciation and risk assessment of heavy metals in the river estuarine sediments - a case study: Mahanadi basin, India. Journal of Hazardous Materials, 186(2), 1837-1846.

Tokalioglu, S., Kartal, S. and Elci, L. 2000. Speciation and determination of heavy metals in lake waters by atomic absorption spectrometry after sorption on amberlite XAD-16 resin. Analytical Sciences, 16(11), 1169-1174. 